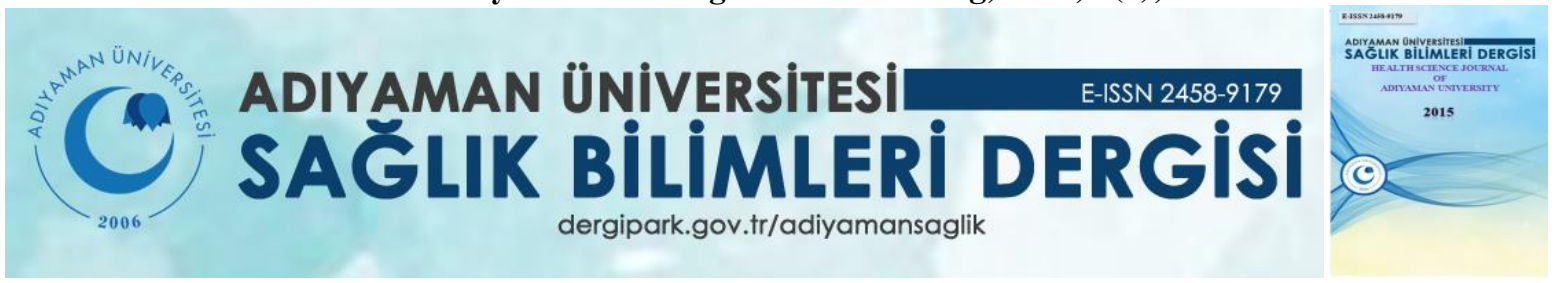

\title{
Araştırma/Research \\ Is there any association between ABO blood types and slow coronary flow?
}

Hakan KAYA ${ }^{1}$

Adıyaman Üniversitesi Eğitim Araştırma Hastanesi Kardiyoloji Kliniği, Türkiye

\begin{abstract}
Aim: Slow coronary flow (SCF) is defined as a microvascular disorder characterized by slow advance of the contrast material administered during angiography, despite absence of epicardial coronary artery occlusion and delayed opacification of distal vascular structures. Genetically inherited ABO blood types are presumed to play role in coronary artery disease. In this study, the relationship between SCF and $\mathrm{ABO}$ blood types was investigated.
\end{abstract}

Methods: The study was designed as a retrospective study, and included 250 cases that underwent coronary angiography procedure in our center between 2016 January and 2018 December (one hundred and twenty five cases of SCF and 125 cases of normal coronary angiogram). ABO blood types were determined using standard agglutination techniques in both study groups. Blood types were compared between both subject groups.

Results: The frequency of blood type A was increased among patients with SCF in comparison with control subjects $(\mathrm{p}<0.001)$. High density lipoprotein cholesterol was increased in SCF group ( $<<0.001)$. Triglyceride, , total cholesterol and low density lipoprotein cholesterol levels were increased in the SCF group when compared to controls ( $\mathrm{p}=0.003, \mathrm{p}<0.001$, and $\mathrm{p}<0.001$, respectively).

Conclusion: This study demonstrated that blood group A may be an increased risk for SCF.

Keywords: ABO blood types, slow coronary flow.

\begin{tabular}{l}
\hline Yazışmadan Sorumlu Yazar \\
\hline Hakan KAYA \\
Adıyaman Üniversitesi Kardiyoloji AD. \\
Adıyaman. Turkey \\
Tel : +90(0416) 2161015 \\
Email: kardiyolog02@gmail.com \\
\hline
\end{tabular}

Doi: 10.30569.adiyamansaglik. 552822

\begin{tabular}{ll}
\hline Geliş Tarihi: & 12.04 .2019 \\
\hline Kabul Tarihi: & 19.06 .2019 \\
\hline
\end{tabular}




\section{Kan grupları ve koroner yavaş akım arasında herhangi bir ilişki var mı?}

\section{ÖZET}

Amaç: Yavaş koroner akım (YKA), epikardiyal koroner arter tıkanıklığı olmamasına rağmen, anjiyografi sırasında uygulanan kontrast maddenin yavaş ilerlemesi ve distal vasküler yapıların gecikmeli opaklaşması ile karakterize bir mikrovasküler bozukluk olarak tanımlanmaktadır. Genetik olarak taşınan $\mathrm{ABO}$ kan gruplarının koroner arter hastalığında rol oynadığı varsayılmaktadır. $\mathrm{Bu}$ çalışmada YKA ve ABO kan grupları arasındaki ilişski araştırıldı.

Gereç ve yöntemler: Çalışma retrospektif bir çalışma olarak tasarlandı ve merkezimizde Ocak 2016 Aralık 2018 tarihleri arasında koroner anjiyografi prosedürü uygulanan 250 vaka (125 YKA hastası ve 125 normal koroner anjiyogram vakası) çalışmaya dahil edildi.Her iki çalışma grubunda da ABO kan tipleri standart aglütinasyon teknikleri kullanılarak belirlendi. Her iki grup arasında kan tipleri karşılaştırıldı.

Bulgular: YKA hastalarında A kan grubu sıklığı kontrol grubuna kıyasla artmıştı $(\mathrm{p}<0.001)$. Kontol grubunda yüksek dansiteli lipoprotein kolesterol artmıştı $(p<0.001)$. Kontrol grubuna kıyasla trigliserit, total kolesterol ve düşük dansiteli lipoprotein kolesterol düzeyleri YKAgrubunda artmıştı ( $p=0.003$, $\mathrm{p}<0.001, \mathrm{p}<0.001$, sirasiyla).

Sonuç: Bu çalışma, A kan grubunun YKA için artmış bir risk olabileceğini ortaya koydu.

Anahtar sözcükler: $A B O$ kan grupları, yavaş koroner akım

\section{INTRODUCTION}

SCF is a clinical condition categorized by slow advance of the administered contrast material within epicardial arteries without any angiographic sign of arterial occlusion (1). SCF has been shown to cause chest pain during exercise or at rest and the pathophysiology of SCF is still not clear. Currently, endothelial dysfunction, microvascular and vasomotor dysfunction, and increased thrombotic and inflammatory activities are believed to be possible contributors to this condition (2-4). Several studies have documented the presence of myocardial ischemia with non-invasive tests in patients with $\operatorname{SCF}(5,6)$.

ABO blood type antigens are made of glycoproteins that are abundant on platelets, vascular endothelial cells, and erythrocytes (7). Multiple reports have demonstrated an association between $\mathrm{ABO}$ blood types and cardiovascular disease (8-10). It is well known that genetics can cause coronary artery disease. Since ABO blood types are genetically inherited, they may be involved in cardiovascular disease development. 
In this retrospective case control study, the effect of ABO blood types on SCF was examined

\section{METHODS}

\section{Study Design and Study population}

A total of 250 subjects that underwent coronary angiography in our clinic between 2016 January and 2018 December were enrolled in the study. Angiographic images were evaluated retrospectively. One hundred and twenty five patients, who had SCF during angiography, were included in the study. One hundred and twenty five subjects, who had normal coronary arteries were designated the control group. Clinical and laboratory information including age, sex, diabetes mellitus (DM), blood pressure, smoking status, height, body weight, ABO blood type, and lipid profile were retrieved from the medical records. Echocardiography findings were obtained from medical records. Left ventricular ejection fraction measured by simpson method. The study exclusion criteria were presence of lung or liver disease, chronic kidney disease, heart disease, infection, and hematological disease or systemic rheumatoid disease.This study was accepted by the ethics committeeand carried out with the guidelines put forth by the Declaration of Helsinki.

\section{Laboratory parameters}

A peripheral venous blood sample was collected from the antecubital vein before coronary angiography at our center. ABO blood typing was performed using a hemagglutination technique (Biotest, Germany) according to the manufacture's protocol. HDLC, TG, LDL-C, and TC levels were analyzed using an Abbott Architect C16000 analyzer (Abbott Laboratory).

\section{TIMI Frame Count for Diagnosis of SCF}

Coronary angiography was achieved using the femoral approach and the angiograms were examined for SCF. Assessment of SCF was doneby two independent blind observers and TIMI frame count used for for diagnosis of SCF (11). The mean values for coronary arteries visualization frames were, $22.2 \pm 4.1$ for LCx,36.2 \pm 2.6 for LAD and $20.4 \pm 3$ for RCA.

\section{Statistical analysis:}


The SPSS, v 22.0, statistical progam (Chicago, USA) was used.Numerical and Categoricalvariables were given as mean $\pm \mathrm{SD}$ and percentage, respectively.For numerical variables, statistical analyses were made with independent samples using t-test/Mann-Whitney U-test. For categorical variables,chi-square test or Fisher's exact testwas used. A p-value $<0.05$ was considered statistically significant.

\section{RESULTS}

Baseline demographic,laboratory and echocardiographic findings of groups are shown in Table 1. Age, gender, BMI, smoking status, DM, systolic/diastolic blood pressures were similar in both groups ( $p>0.05$ for all).High density lipoprotein cholesterol(HDL-C) was higher in control group than SCF group $(\mathrm{p}=0.003)$. Low density lipoprotein cholesterol (LDLC), triglyceride (TG) and totalcholesterol (TC) were elevated in SCF group as compared to the controls $(\mathrm{p}=0.003, \mathrm{p}<0.001, \mathrm{p}<0.001$, and $\mathrm{p}<0.001$, respectively).

Table 1. The demographic, laboratory and echocardiographic findings of groups

\begin{tabular}{|l|l|l|l|}
\hline Variables & SCF group & Control group & P value \\
\hline & $(\mathrm{n}=125)$ & $(\mathrm{n}=125)$ & \\
\hline Age $($ years) & $51,0 \pm 7,2$ & $51,3 \pm 7,6$ & 0,793 \\
\hline Gender, male n \% & $99(79,2)$ & $102(81,6)$ & 0,633 \\
\hline BMI $\left(\mathrm{kg} / \mathrm{m}^{2}\right)$ & $25,9 \pm 3,0$ & $25.7 \pm 3,1$ & 0,719 \\
\hline Diabetes mellitus n (\%) & $11(8,8)$ & $7(5,6)$ & 0,328 \\
\hline Smoking $(\%)$ & $46(32,8)$ & $41(36.8)$ & 0,507 \\
\hline Systolic BP $(\mathrm{mmHg})$ & $128,9 \pm 6,2$ & $125,4 \pm 11,2$ & 0,169 \\
\hline Diastolic BP (mmHg) & $74,8 \pm 5,9$ & $72,4 \pm 5,5$ & 0,621 \\
\hline LVEF $(\%)$ & $60,0 \pm 3,6$ & $62,1 \pm 3,2$ & 0,883 \\
\hline LDL-C $(\mathrm{mg} / \mathrm{dl})$ & $141,5 \pm 31,2$ & $83,1 \pm 19,3$ & $<0,001$ \\
\hline HDL-C (mg/dl) & $42,10 \pm 10,0$ & $38,4 \pm 10,7$ & 0.003 \\
\hline TC $(\mathrm{mg} / \mathrm{dl})$ & $220,8 \pm 30,3$ & $148,1 \pm 20,9$ & $<0.001$ \\
\hline TG $(\mathrm{mg} / \mathrm{dl})$ & $179,7 \pm 74,0$ & $130,7 \pm 61,5$ & $<0.001$ \\
\hline
\end{tabular}

BMI, body mass index; BP, blood pressure; left ventricle ejection fraction; LDL-C, Low density lipoprotein cholesterol; HDL-C, High density lipoprotein cholesterol; TG, triglyceride; TC, total cholesterol.

The frequencies of ABO blood types in the study groups are shown in Table 2. The frequency of blood type A was increased compared in the SCF group in comparison to the control subjects $(\mathrm{p}<0.001)$. No difference regarding the frequency of non-A blood types for the group comparison ( $\mathrm{p}>0.05$ for all). 
Table 2. The frequencies of ABO blood types of groups

\begin{tabular}{|l|l|l|l|}
\hline & SCF group & Control group & P value \\
\hline & $(\mathrm{n}=125)$ & $(\mathrm{n}=125)$ & \\
\hline $\mathrm{A}, \mathrm{n} \%$ & $56(44,8)$ & $29(23,2)$ & $<0.001$ \\
\hline $\mathrm{B}, \mathrm{n} \%$ & $20(16,0)$ & $35(28,0)$ & 0,168 \\
\hline $\mathrm{AB}, \mathrm{n} \%$ & $33(26,4)$ & $46(36,8)$ & 0,266 \\
\hline $\mathrm{O}, \mathrm{n} \%$ & $16(12,8)$ & $15(12,0)$ & 0.844 \\
\hline
\end{tabular}

\section{DISCUSSION}

The association between SCF and ABO blood types were investigated in the present study. An association was found between blood type A and SCF. Recently, several studies examined the relationship between ABO blood types and coronary artery disease, and showed that non-A blood groups were associated with CAD $(12,13)$. The present study is the first study to examine the association between $\mathrm{SCF}$ and $\mathrm{ABO}$ blood types.

SCF is responsible for nearly $7.0 \%$ of all cases undergoing coronary angiography due chest pain and suspicion of CAD (14). Cardiac functions are compromised in the case of SCF. Patients with SCF have been shown to have abnormalities of ventricular diastolic function, subclinical atherosclerosis, ventricular conductance disturbances, cardiac autonomic dysfunction, and increased ventricular arrhythmia (15-18). Patients with SCF have increased cardiac mortality and morbidity (19). Several studies have shown an important role of increased inflammatory activity in pathophysiology of cardiovascular disease and arrhythmia (20). Increased inflammatory activity has also been documented in patients with SCF. The pathogenic mechanism regarding the association between blood type A and SCF may involve various causes. The ATP Binding Cassette 2 (ABCA2) gene and the ABO gene are both located on chromosome 9q34. In parallel with this information, this study showed significantly increased levels of LDL, TG, and TC among patients with SCF, whom have significantly higher frequency of blood type A compared to the control group. The high cholesterol levels might play role in development of microvascular disease, which is responsible for pathogenesis of SCF. Blood type antigen A is expressed not only on the red blood cells but also on other cells such as platelets and vascular endothelial cells [7]. In addition, non-O blood types have high plasma levels of von Willebrand factor, which increase the risk of vascular thrombosis. As 
conclusion, increased thrombotic activity and microvascular disease in the case of blood types A might be responsible for development of SCF. Some genetic studies have defined ABO gene as an important site for LDL cholesterol metabolism and the inflammatory biomarkers ICAM1, E-selectin, and P-selectin. These molecules play active roles in hemostasis and inflammation. Blood type antigen A may modulate the risk of SCF by influencing the levels of hemostasis and inflammatory proteins in circulation.

Major limitations of the present study are its single-centered design and the few numbers of patients. Another limitation is that inflammatory markers and hemostasis markers were not measured

In conclusion, this study findings suggest that blood type A may pose an increased risk for SCF. However to investigate the association between ABO blood types and SCF, largescale, multi-centered studies that correlate ABO genotypes with hemostatic and inflammatory markers are required.

\section{REFERENCES}

1. S. Xia, S. B. Deng, Y. Wang et al: Clinical analysis of the risk factors of slow coronary flow. Heart Vessels 2011; $26: 480-486$

2. Pekdemir H, Cin VG, Cicek D, et al: Slow coronary flow may be a sign of diffuse atherosclerosis. Contribution of FFR and IVUS. Acta Cardiol 2004; 59: 127-133.

3. Van Lierde J, Vrolix M, Sionis D, et al: Lack of evidence for small vessel disease in a patient "with slow dye progression " in the coronary arteries. Cathet Cardiovasc Diagn 1991; 23: 117-120.

4. Madak N, Nazlı Y, Mergen H, et al: T.Acute phase reactants in patients with coronary slow flow phenomenon. Anadolu Kardiyol Derg 2010; 10: 416-420.

5. I. Barutcu, A. T. Sezgin, H. Gullu, et al: Slow coronary flow phenomenon associated with exercise-induced myocardial ischemia. Turkish Journal of thoracic and Cardiovascular Surgery 2005; 13: 295-297.

6. L. A. Cesar, J. A. Ramires, C. V. Serrana Junior et al: Slow coronary runoff in patient with angina pectoris: clinical significance and thallium-201 scintigraphic study. Brazilian Journal of Medical and Biological Research 1996; 29: 605-613.

7. Eastlund T: The histo-blood group ABO system and tissue transplantation. Transfusion 1998; 38: $975-988$.

8. Carpeggiani C, Coceani M, Landi $\mathrm{P}$, et al: ABO blood group alleles: a risk factor for coronary artery disease. An angiographic study. Atherosclerosis 2010; 211: 461-466.

9. Zhang H, Mooney CJ, Reilly MP. ABO blood groups and cardiovascular diseases. Int J Vasc Med 2014; 58: 524-528. 
10. Biancari F, Satta J, Pokela R, et al: ABO blood group distribution and severity of coronary artery disease among patients undergoing coronary artery bypass surgery in Northern Finland. Thromb Res 2002; 108: 195-196.

11. Gibson CM, Cannon CP, Daley WL, et al: TIMI frame count: a quantitative method of assessing coronary artery flow. Circulation 1996; 93: 879-888.

12. Hsin-Fu Lee, Yen-Chen Lin, Chia-Pin Lin, et al: Association of Blood Group A with Coronary Artery Disease in Young Adults in Taiwan. Intern Med 2012; 51: 1815-1820.

13. Ahmet Kaya, İbrahim Halil Tanboga, Mustafa Kurt, et al: Relation of ABO blood groups to coronary lesion complexity in patients with stable coronary artery disease. Anatol J Cardiol 2014; 14: 55-60.

14. V. Oktay and A. Arat Ozkan: Coronary slow flow. Turk Kardiyoloji Dernegi Arsivi-Archives of the Turkish Society of Cardiology 2016; 44: 193-195.

15. Elsherbiny IA: Left ventricular function and exercise capacity in patients with slow coronary flow. Echocardiography 2012; 29: 158-164.

16. Acikel S, Bozkaya OA, Akdemir R: The relationship between intermittent left bundle-branch block and slow coronary flow in a patient presenting with acute coronary syndrome. Blood Coagul Fibrinolysis 2010; 21: 595-597.

17. Kosus A, Sagkan O, Dursun I: Heart rate variability and QT dispersion in patients with slow coronary flow. Turk Kardiyol Dern Ars 2004; 32: 10-15.

18. Saya S, Hennebry TA, Lozano P, et al: Coronary slow flow phenomenon and risk for sudden cardiac death due to ventricular arrhythmias: a case report and review of literature. Clin Cardiol 2008; 31: 352-355.

19. Atak R, Turhan H, Sezgin AT, et al: Effects of slow coronary artery flow on QT interval duration and dispersion. Ann Noninvasive Electrocardiol 2003; 8: 107-111.

20. L agrand $\mathrm{W} \mathrm{K}, \mathrm{V}$ isser C A, H ermens W T, et al: C-reactive protein as a cardiovascular risk factor: more than an epiphenomenon? Circulation 1999; 100: $96-102$. 